\title{
Strength and Durability Research on Concrete with Partial Replacement of Cement by Rice Husk Ash and Spent Bleaching Earth
}

\author{
G Lalitha Devi, K Srinivasa Pasad, M Swaroopa Rani, L Bhanu
}

\begin{abstract}
Concrete is the foremost building material in the region of the sphere and used in operational works, including infrastructure, low and high-rise buildings. Substitution of waste materials will conserve dwindling resources, and will avoid the environmental and ecological damages caused by quarrying and exploitation of the raw materials for making cement. So we are interested in replacement of cement with waste materials coming from oil industry and rice mill industry. So we are taking spent bleach earth (SBE) from oil industry \& rice husk ash (RHA) from rice milling industry. W/c ratio as 0.38 and SP 430 IS used for obtaining required slump. The required slump is arrived at $0.7 \%$ of admixture. Following replacing the Cement with SBE 5\%, $7.5 \%, 10 \%$ and $\mathrm{RHA}$ with $2 \%, 4 \%, 6 \%, 8 \%, 10 \%$ aimed at optimum results. Now SBE5\% \& RHA 8\% got optimum values. Subsequently beams, cylinders, cubes are casted. Compressive strength, Split tensile strength, Flexural strength originate for 7 days \& 28 days. Later 28 days curing cubes are placed in Hydrochloric acid (HCL) for durability test. For durability test cubes are submerged in 5\% of HCL for additional 28days \& find the Compression strength.
\end{abstract}

Index Terms-Compressive strength, $\mathrm{HCl}, \mathrm{RHA}, \mathrm{SBE}$.

\section{INTRODUCTION}

The use of business and agricultural wastes as supplementary materials in concrete production is changing into common and attracting attention of the many researchers. Spent mud and rice husk ash area unit waste materials arising from process of extraction of oil from feather palm dotty.

Spent mud (SBE) may be a solid waste generated in edible oil business. because of the high oil content within the compass point, its disposal will cause environmental hazards, since it's susceptible to catching fireplace, besides polluting the bottom water. With the restrictive restrictions in situ in most countries, the requirement to reduce the environmental impact is of growing importance and concern to the trade. sometimes compass point is disposed of in landfills or waste dumps

Rice husk ash (RHA) is associate cultivated primarily

Revised Version Manuscript Received on 16 September, 2019.

G Lalitha Devi, Asst.Prof,KITS Divili , East Godavari, Divili, Andhra Pradesh, India.

(Email: lalithadevi.ce@gmail.com)

K Srinivasa Pasad, Asst.Prof,KITS Divili, East Godavari, Divili, Andhra Pradesh, India.

(Email: ssrinivas66@gmail.com)

Dr. M Swaroopa Rani, Professor, JNTUK, Kakinada, Andhra Pradesh, India

(Email: swaroopa0333@gmail.com)

L Bhanu, Asst.Prof,KITS Divili, East Godavari, Divili, Andhra Pradesh, India.

(Email: prakashbhanu123@gmail.com) based pozzolanic material, created by rice mills in large quantities. therein eightieth of rice and two hundredth of husk was found throughout edge of paddy. This husk is employed as fuel in industries to get steams and alternative functions. This husk holds concerning seventy five nada organic fickle material and also the lasting twenty five you look after the load of this husk is reworked into ash throughout the firing method, this ash is thought as RHA.

However, the performance of concrete made with blended cement-SBE and RHA concrete in acidic environment has not been reported. Therefore, the thrust of this project is to investigate the engineering properties and effect of hydrochloric acid on the strength of the concrete in which cement is partially replaced by SBE and RHA.

\section{MATERIALS USED}

Ordinary Portland cement was used for the present study. Rice husk ash and spent bleaching earth obtained from local industries is sieved through 90 microns sieve. It is used to replace cement partially. The chemical composition of cement, RHA and SBE are tested. River sand and granite of maximum nominal sizes of $3.18 \mathrm{~mm}$ and $20 \mathrm{~mm}$ were used as fine and coarse aggregate respectively. Potable water was used for mixing. The Hydrochloric acid is taken from the scientific laboratory through civil engineering department and different concentrations of its solution are prepared in the laboratory.

\section{METHODOLOGY}

Concrete mix proportion of 1:1.74:3.06 (cement/RHA/SBE: sand: Coarse aggregate) is batched by weight. Cement is replaced with RHA in the proportions of 2, $4,6,8$ and $10 \%$ of the weight of cement and SBE in proportions of $5,7.5$ and $10 \%$ of weight of cement are use. Seventy two concrete cubes of sizes 150x150 mm, Twenty eight Cylinders $150 \times 300 \mathrm{~mm}$ and Twenty four beams $150 \times 150 \times 700 \mathrm{~mm}$ are cast and cured for 28 days in water. After 28 days some cubes are removed from water and immersed in Hydrochloric acid (HCL) solutions of $5 \%$ concentration for another 28days. On expiry of each curing age, cubes are tested for compressive strength. 


\section{MATERIAL PROPERTIES}

A. Cement

Table I Physical properties of cement

\begin{tabular}{|l|l|l|}
\hline S.No & Property & Test results \\
\hline 1 & Normal consistency & $30 \%$ \\
\hline 2 & Specific gravity & 3.15 \\
\hline 3 & Initial setting time & $95 \mathrm{~min}$ \\
\hline 4 & Final setting time & $205 \mathrm{~min}$ \\
\hline 5 & Fineness & $4 \%$ \\
\hline
\end{tabular}

\section{B. Fine Aggregates}

Table II Physical properties of Fine Aggregates

\begin{tabular}{|l|l|l|}
\hline S.No & Property & Test result \\
\hline 1 & Specific Gravity & 2.54 \\
\hline 2 & Fineness Modulus & 2.642 \\
\hline 3 & $\begin{array}{l}\text { Bulk Density in loose } \\
\text { state }\end{array}$ & $1578 \mathrm{~kg} / \mathrm{m} 3$ \\
\hline 4 & $\begin{array}{l}\text { Bulk Density in } \\
\text { compact state }\end{array}$ & $1718 \mathrm{~kg} / \mathrm{m} 3$ \\
\hline 5 & Grading & Zone II \\
\hline
\end{tabular}

\section{Coarse Aggregates}

Table III Physical properties of Fine Aggregates

\begin{tabular}{|l|l|l|}
\hline S.No & Property & Test result \\
\hline 1 & Specific Gravity & 2.73 \\
\hline 2 & Fineness Modulus & 6.02 \\
\hline 3 & $\begin{array}{l}\text { Bulk Density in loose } \\
\text { state }\end{array}$ & $1422 \mathrm{Kg} / \mathrm{m} 3$ \\
\hline 4 & $\begin{array}{l}\text { Bulk Density in } \\
\text { compact state }\end{array}$ & $1555 \mathrm{~kg} / \mathrm{m} 3$ \\
\hline 5 & $\begin{array}{l}\text { Nominal maximum } \\
\text { size }\end{array}$ & $20 \mathrm{~mm}$ \\
\hline
\end{tabular}

D. Rice Husk Ash (RHA) \& Spent Bleach Earth (SBE)

Table IV Physical properties of RHA \& SBE

\begin{tabular}{|l|l|l|l|}
\hline S.No & $\begin{array}{l}\text { Physical } \\
\text { properties of } \\
\text { material }\end{array}$ & S.B.E & RHA \\
\hline 1 & Specific Gravity & 2.00 & 2.2 \\
\hline 2 & Fineness & $9 \%$ & $7 \%$ \\
\hline 3 & Colour & Brown & Black \\
\hline
\end{tabular}

\section{E. Hydrochloric Acid ( $\mathrm{HCl})$}

Table V Physical properties of $\mathrm{HCl}$

\begin{tabular}{|l|l|l|}
\hline 1 & Empirical formula & HCL \\
\hline 2 & Molecular weight & 36.47 \\
\hline 3 & Melting point & $-180 \mathrm{C}$ \\
\hline 4 & Boiling point & $1030 \mathrm{C}$ \\
\hline 5 & Specific heat & $3.47 \mathrm{~kJ} / \mathrm{kg}$ \\
\hline 6 & Density & $1.048 \mathrm{~kg} / \mathrm{L}$ \\
\hline
\end{tabular}

\section{F. Water}

Table VI Physical properties of Water

\begin{tabular}{|l|l|l|}
\hline S. No & Property & Value \\
\hline 1 & PH & 6.90 \\
\hline 2 & Taste & Agreeable \\
\hline 3 & Appearance & Clear \\
\hline
\end{tabular}

\section{G. Super Plasticizer (SP)}

Conplast SP430 is used for this investigation. It is used for obtaining high degree workability and its retention are required, where delays in transportation or placing are likely or when high ambient temperatures cause rapid slump loss. It facilitates production of high quality concrete. Conplast SP430 obeys with IS:9103:1999 and BS:5075 Part 3 and ASTM-C-494 variety ' $F$ ' on a high range water reducing admixture and Variety $\mathrm{G}$ on high dosage. Conplast SP430 was used to give $25 \%$ of water reductions without loss of workability or to produce high quality of concrete with reduced permeability.

\section{OBJECTIVE OF THE PROJECT}

The objectives of this experimental project study are

- To study the effect of concrete, when Cement is partially replaced with Rice husk ash and Spent bleaching earth.

- To study the workability, strength and durability properties of concrete of grades M30.

This work presents the laboratory investigations carried out studies on fresh and hardened properties of concrete.

\section{EXPERIMENTAL INVESTIGATION}

In the present study, concrete of M30 grade with water-cement ratio of 0.38 is considered. This study examined the Mix design for M30 with partial replacement of cement with rice husk ash and Spent bleach earth.(i.e., Control mix, 2\%RHA, 4\%RHA, 6\%RHA, 8\%RHA, $10 \%$ RHA, $5 \%$ SBE, $7.5 \%$ SBE, $10 \%$ SBE) based on the IS 10262-2009. With the above variables 66 cubes were cast and tested at the age of 7 and 28 days for compressive strength. From the obtained compressive strength results the optimum percentage of replacement of RHA and SBE, cylinders and beams were cast and tested at the age of 7 and 28 days for split tensile strength and flexural strength. A durability test such as placing in HCL acid is conducted.

Table VII Mix proportions of concrete (quantities in $\mathrm{kg} / \mathrm{m}^{3}$ )

\begin{tabular}{|c|c|c|c|c|c|c|c|c|}
\hline \multirow{2}{*}{ Mix Plan } & \multirow{2}{*}{ w/c } & $\begin{array}{c}\% \\
\text { Variation }\end{array}$ & \multicolumn{2}{|c|}{ Binder(kg) } & Water & CA (kg) & FA(kg) & $\begin{array}{c}\text { SP430 } \\
\text { (Lt) }\end{array}$ \\
\hline $\begin{array}{c}\text { Control } \\
\text { Mix }\end{array}$ & 0.38 & 0 & 400 & 0 & 152 & 1220.53 & 696 & 2.39 \\
\hline RHA 2\% & 0.38 & 2 & 392 & 8 & 152 & 1220.53 & 696 & 2.39 \\
\hline RHA 4\% & 0.38 & 4 & 384 & 16 & 152 & 1220.53 & 696 & 2.39 \\
\hline RHA 6\% & 0.38 & 6 & 376 & 24 & 152 & 1220.53 & 696 & 2.39 \\
\hline RHA 8\% & 0.38 & 8 & 368 & 32 & 152 & 1220.53 & 696 & 2.39 \\
\hline RHA 10\% & 0.38 & 10 & 360 & 40 & 152 & 1220.53 & 696 & 2.39 \\
\hline SBE 5\% & 0.38 & 5 & 380 & 20 & 152 & 1220.53 & 696 & 2.39 \\
\hline SBE 7.5\% & 0.38 & 7.5 & 370 & 30 & 152 & 1220.53 & 696 & 2.39 \\
\hline SBE 10\% & 0.38 & 10 & 360 & 40 & 152 & 1220.53 & 696 & 2.39 \\
\hline C+R8+S5 & 0.38 & $8+5$ & 348 & 52 & 152 & 1220.53 & 696 & 2.39 \\
\hline
\end{tabular}




\section{RESULTS AND DISCUSSION}

\section{A. Slump cone test}

The slump values for different $\%$ of spent bleaching earth and Rice husk ash are decreasing due to absorption of water. The slump values are tabulated below. The results are also shown in graphical form.

Observation: It is observed that the slump values are decreasing with increase of $\%$ of spent bleaching earth.

Table VIII Slump values for different $\%$ of SBE

\begin{tabular}{|l|l|l|}
\hline S.No & $\%$ of SBE & Slump in $\mathrm{mm}$ \\
\hline 1 & $0 \%$ & 80 \\
\hline 2 & $5 \%$ & 30 \\
\hline 3 & $7.5 \%$ & 20 \\
\hline 4 & $10 \%$ & 5 \\
\hline
\end{tabular}

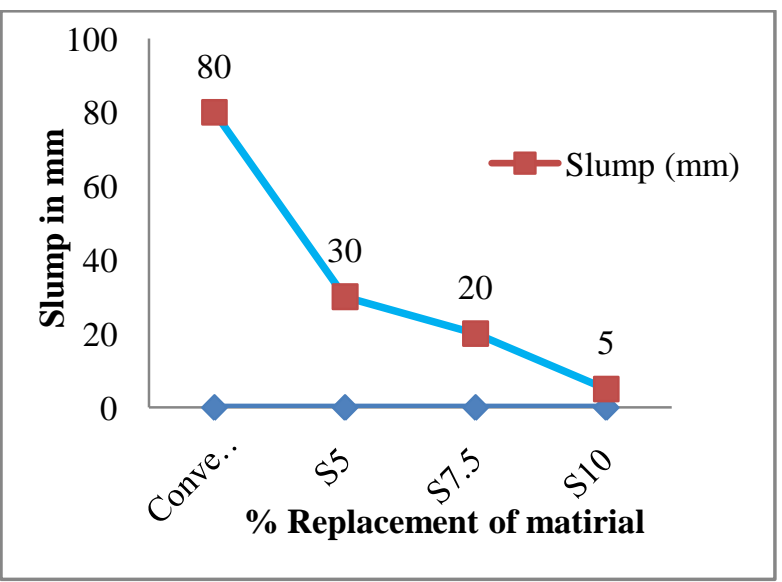

Graph 1. Slump Vs \% of Spent bleaching earth

Table IX Slump values for different \% of R.H.A.

\begin{tabular}{|l|l|l|}
\hline S.No & $\%$ of R.H.A. & Slump in $\mathrm{mm}$ \\
\hline 1 & $0 \%$ & 80 \\
\hline 2 & $2 \%$ & 75 \\
\hline 3 & $4 \%$ & 40 \\
\hline 4 & $6 \%$ & 35 \\
\hline 5 & $8 \%$ & 30 \\
\hline 6 & $10 \%$ & 10 \\
\hline
\end{tabular}

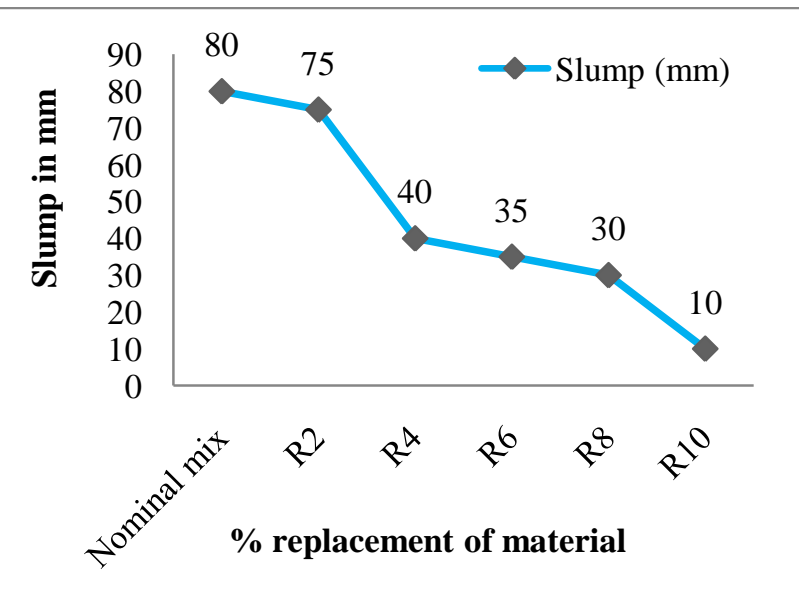

Graph 2. Slump Vs \% of Rice husk ash

\section{B. Compressive Strength}

The compressive strength of concrete was done on 150x150x150 mm cubes. Testing of the specimens was done

at 7 days and 28 days, at the rate of three cubes for each mix that particular day. The average value of the 3 specimens is reported as the strength at that particular age.

The compressive strength test was conducted for all the mixes and the results are shown in below

Table X Compressive strength of concrete for SBE replacement

\begin{tabular}{|l|l|l|l|}
\hline S.no & $\begin{array}{l}\% \text { of S.B.E } \\
\text { replaced in } \\
\text { cement }\end{array}$ & $\begin{array}{l}\text { Compressive } \\
\text { strength in } \\
\text { N/mm2 }\end{array}$ & \\
\hline & & 7 days & 28 days \\
\hline 1 & $0 \%$ & 35.11 & 42.66 \\
\hline 2 & $5 \%$ & 34.44 & 42.88 \\
\hline 3 & $7.5 \%$ & 19.11 & 21.77 \\
\hline 4 & $10 \%$ & 10.22 & 18.44 \\
\hline
\end{tabular}

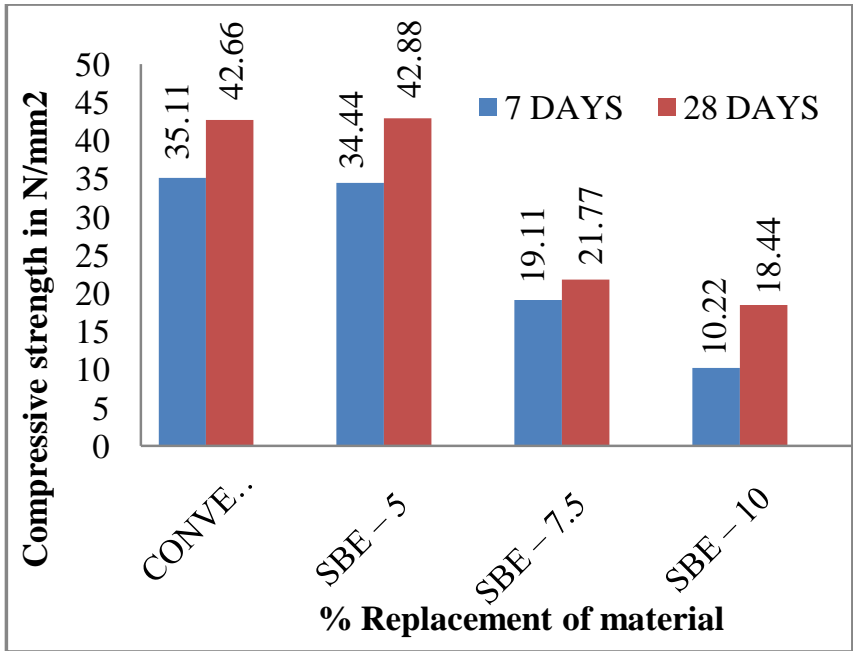

Graph 3. Compressive strength of concrete for different $\%$ of S.B.E

Table XI Compressive strength of concrete for different \% of RHA

\begin{tabular}{|l|l|l|l|}
\hline S.no & $\begin{array}{l}\% \text { of RHA } \\
\text { replaced in } \\
\text { cement }\end{array}$ & $\begin{array}{l}\text { Compressive } \\
\text { strength in } \\
\text { N/mm2 }\end{array}$ & \\
\hline & & 7 days & 28 days \\
\hline 1 & $0 \%$ & 35.11 & 42.66 \\
\hline 2 & $2 \%$ & 24 & 28.88 \\
\hline 3 & $4 \%$ & 26.22 & 32.77 \\
\hline 4 & $6 \%$ & 28.55 & 38.33 \\
\hline 5 & $8 \%$ & 30.33 & 42.77 \\
\hline 6 & $10 \%$ & 11.11 & 18.88 \\
\hline
\end{tabular}


Strength and Durability Research on Concrete with Partial Replacement of Cement by Rice Husk Ash and Spent Bleaching Earth

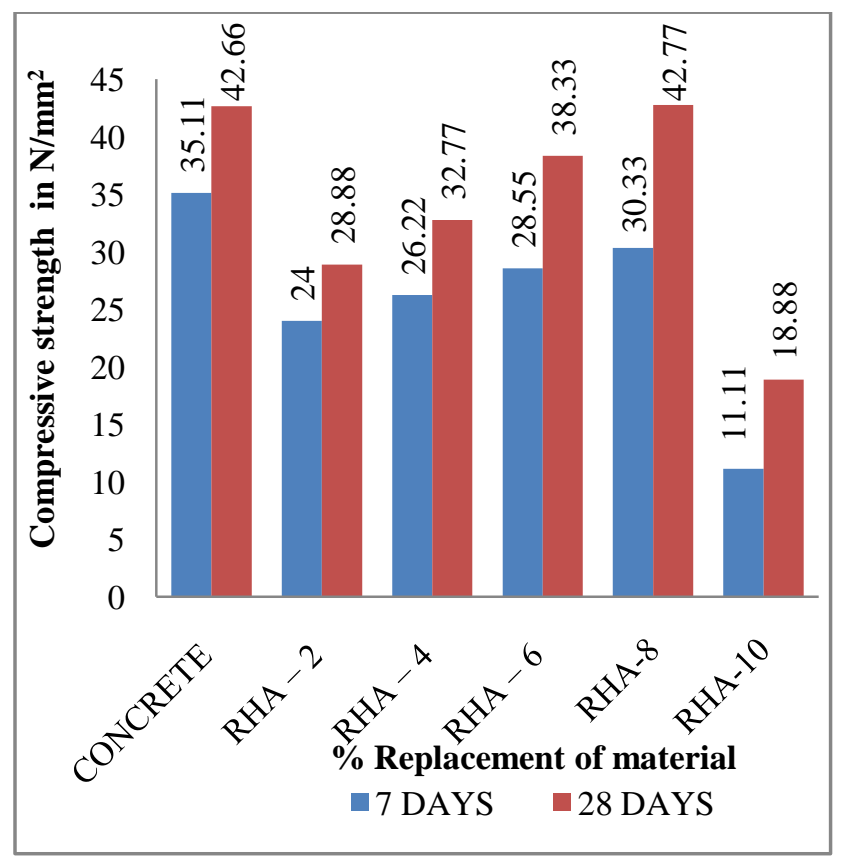

Graph 4. Compressive strength of concrete for different \% of R H A

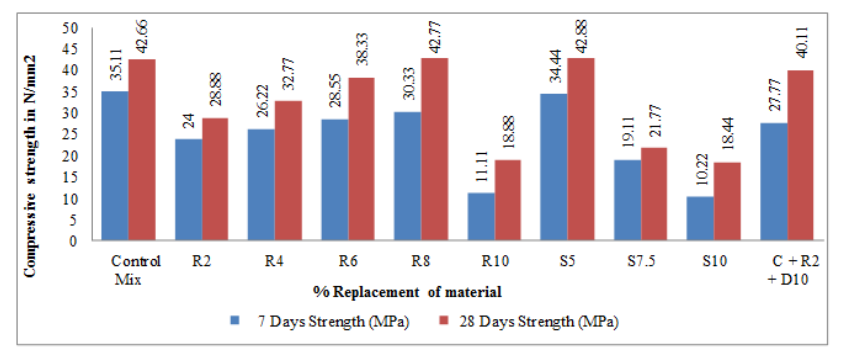

Graph 5. Compressive strength of concrete for different \% of R H A \&SBE

\section{Split Tensile Strength}

Table XII Split tensile strength Vs optimum \% Replacement

\begin{tabular}{|l|l|l|}
\hline $\begin{array}{l}\text { Percentage } \\
\text { Replacement }\end{array}$ & $\begin{array}{l}7 \text { days strength in } \\
\mathrm{N} / \mathrm{mm} 2\end{array}$ & $\begin{array}{l}28 \text { days strength in } \\
\mathrm{N} / \mathrm{mm} 2\end{array}$ \\
\hline Conventional mix & 1.88 & 2.19 \\
\hline R H A-8 & 1.76 & 1.83 \\
\hline S B E-5 & 1.27 & 1.55 \\
\hline C+R8+S5 & 1.41 & 2.47 \\
\hline
\end{tabular}

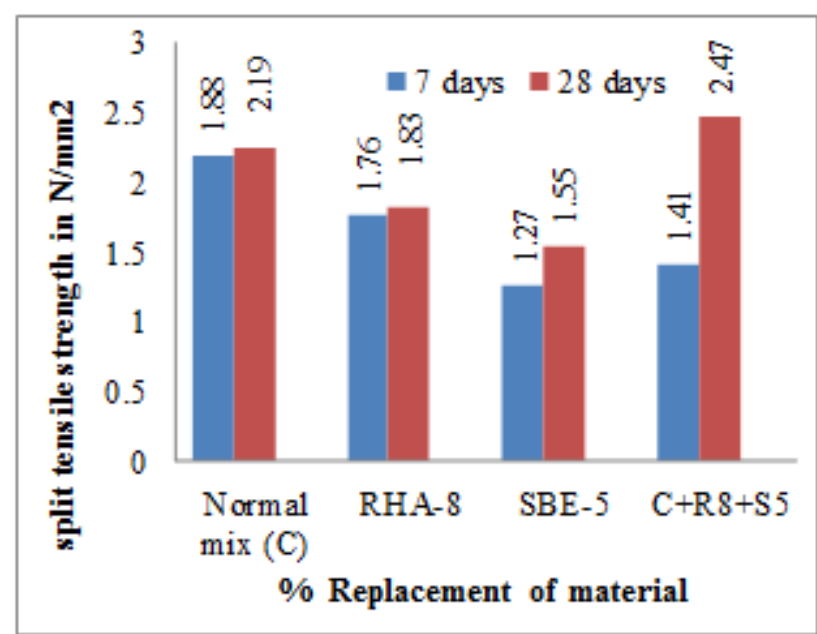

Graph 6. Split tensile strength of concrete for S.B.E Vs R H A

\section{Flexural Strength}

The flexural strength of the concrete was determined from modulus of rupture test on beam specimens of 700x150x150 $\mathrm{mm}$ size.

Here also, a total of 24 specimens were cast out of which three specimens were tested for each mix at 7 days and 28 days.

Table XIII Flexural strength Vs optimum \% Replacement

\begin{tabular}{|l|l|l|l|}
\hline Percentage & 7 days strength in & $\begin{array}{l}28 \text { days strength in } \\
\text { N/mm2 }\end{array}$ \\
\hline Replacement & N/mm2 & 5.73 \\
\hline RHA-8 & 5.39 & 4.36 \\
\hline SBE-53 & 3.62 & 5.03 \\
\hline C+R8+S5 & 3.73 & 4.90 \\
\hline
\end{tabular}

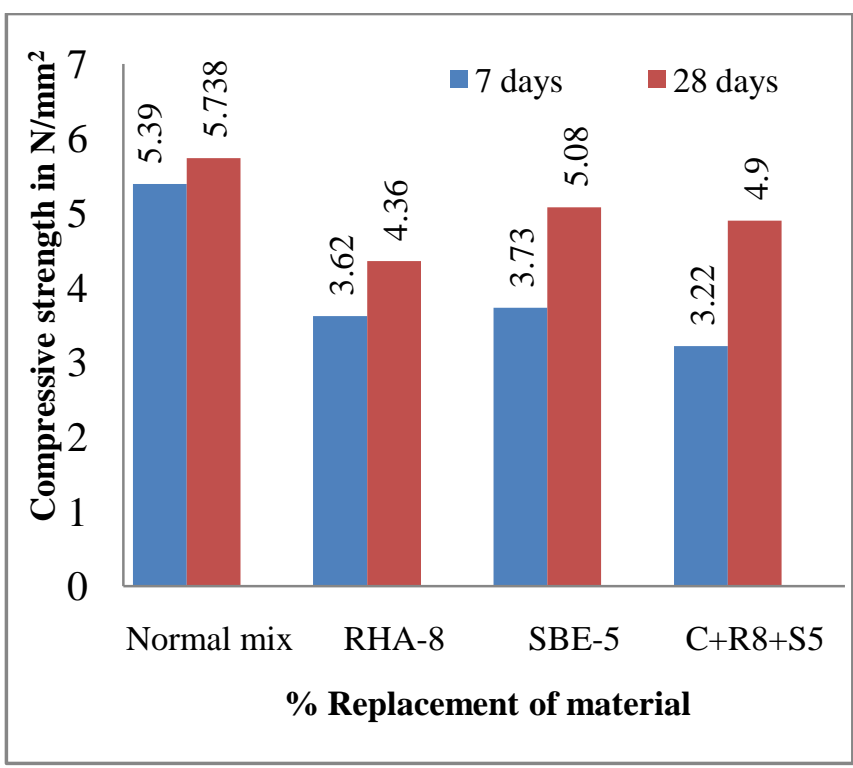

Graph 7. Flexural strength of concrete for S.B.E Vs R H A

E. Durability Test

Compressive Strength

Durability test results at different ages on concrete with replacement of spent bleaching earth and Rice husk ash shown in table XIV.

Table XIV Compressive strength loss for control and replaced mix

\begin{tabular}{|l|l|l|l|}
\hline $\begin{array}{l}\text { Percentage of } \\
\text { Replacement }\end{array}$ & $\begin{array}{l}\text { Strength Before } \\
\text { placing in HCL } \\
\text { acid (N/mm2) }\end{array}$ & $\begin{array}{l}\text { Strength after } \\
\text { Placing in Acid } \\
\text { (N/mm2) }\end{array}$ & $\begin{array}{l}\text { Percentage of } \\
\text { loss }\end{array}$ \\
\hline $\begin{array}{l}\text { Conventional } \\
\text { mix }\end{array}$ & 42.66 & 41.92 & 1.734 \\
\hline RHA-8 & 42.77 & 35.11 & 17.90 \\
\hline SBE-5 & 42.88 & 31.99 & 25.396 \\
\hline C+R8+S5 & 40.11 & 30.82 & 23.161 \\
\hline
\end{tabular}




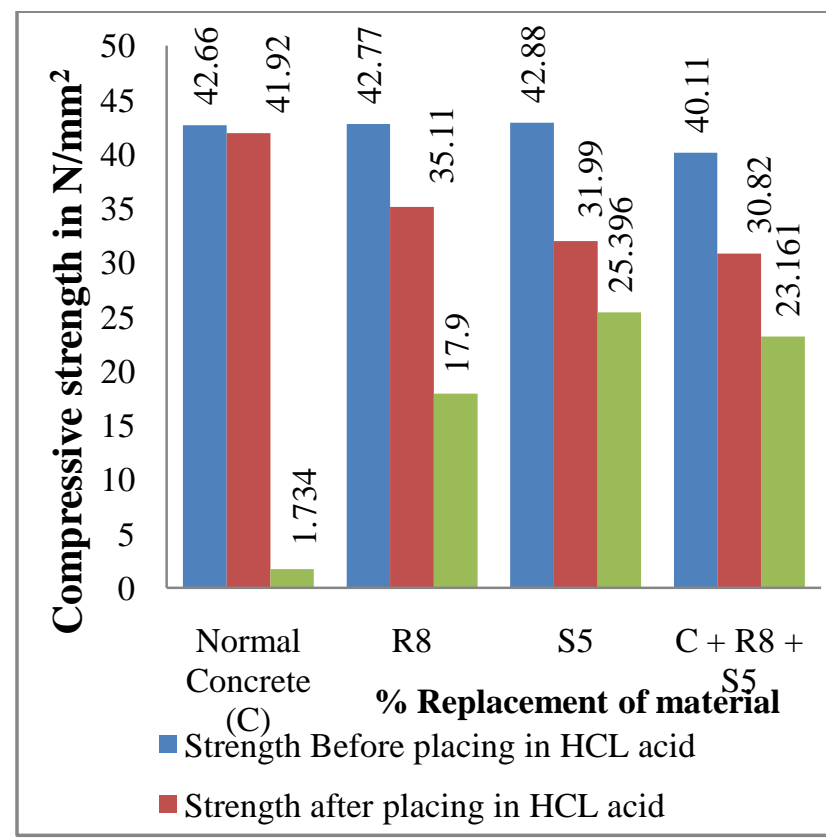

Graph 8. Compressive strength Vs \% Replacement of material

Table XV EC values for the \% replacement material

\begin{tabular}{|l|l|l|}
\hline \multicolumn{1}{|c|}{$\%$ Replacement } & $\begin{array}{c}\mathbf{E}_{\mathrm{C}} \text { Theoritical } \\
5000 \sqrt{f} c k \mathrm{MPa}\end{array}$ & \multicolumn{1}{|c|}{$\begin{array}{c}\mathbf{E}_{\mathrm{C}} \text { Practical } \\
\mathbf{M P a}\end{array}$} \\
\hline Control Mix & 27386 & 21215.2076 \\
\hline R8 & 27386 & 21215.2076 \\
\hline S5 & 27386 & 28286.94275 \\
\hline C+R8+S5 & 27386 & 16972.165 \\
\hline
\end{tabular}

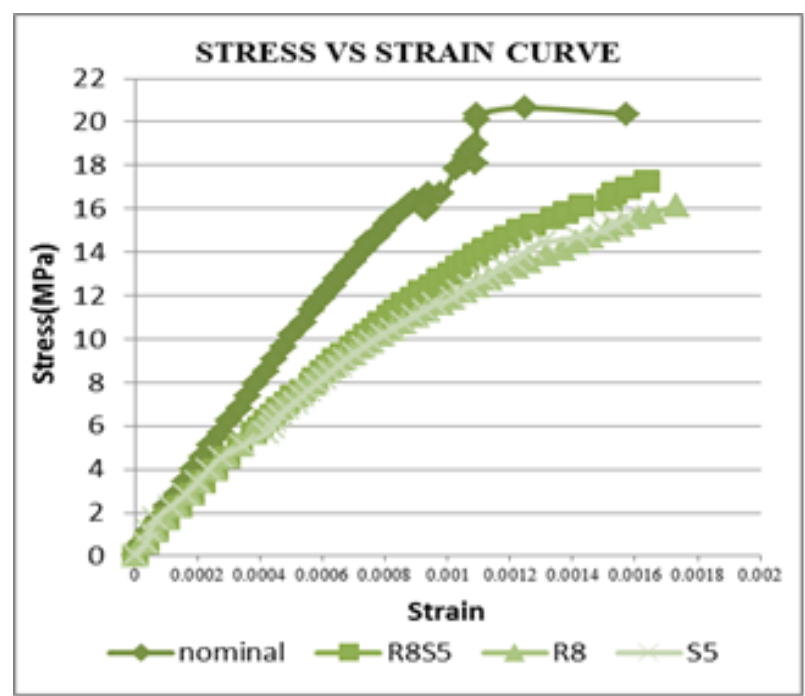

Graph 9. Stress strain curves for \% replacement of mixes

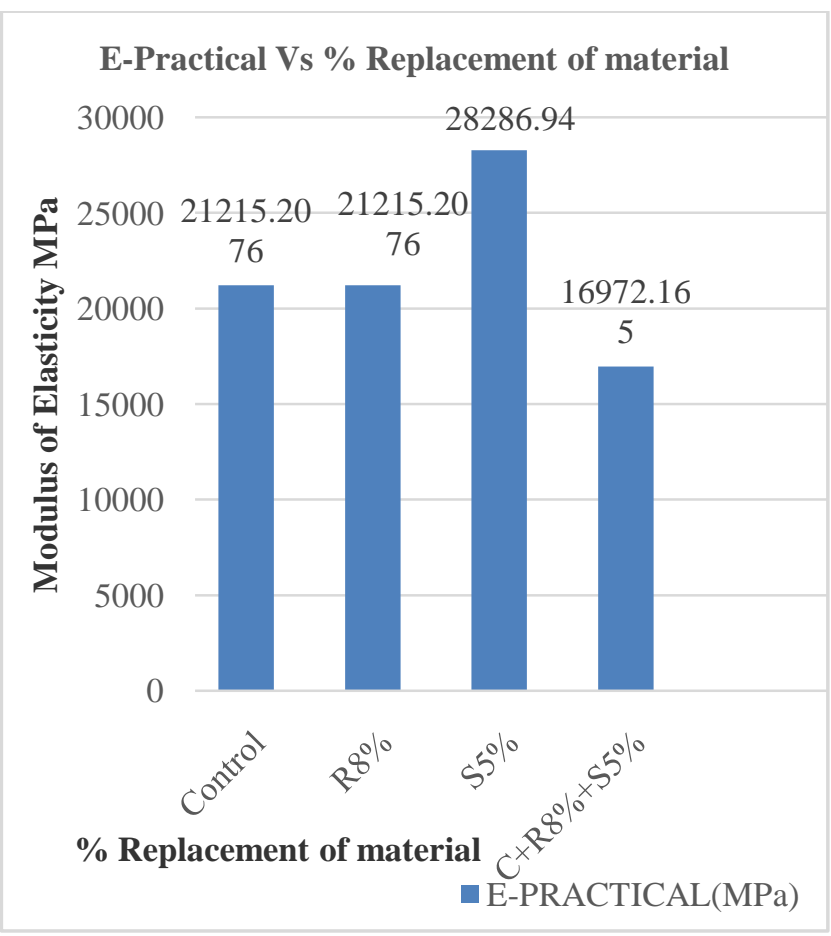

Graph 10. E-Practical Vs \% Replacement of material

\section{CONCLUSION}

Based on the study, following conclusions may be drawn. i. The percentage replacement of cement with RHA, SBE reaches the target strength but gives less strength compared to control concrete mix.

ii. With $0.38 \mathrm{w} / \mathrm{c}$ and $0.7 \%$ of SP430, concrete has low workability, as the slump was true slump.

iii. The workability of concrete was decreased with increased percentage variation of Rice husk ash and De oiled earth.

iv. At $8 \%$ replacement of RHA maximum compressive strength is observed at 7 days i.e $30.33 \mathrm{MPa}$ and at 28 days 42.77MPa respectively.

v. Split tensile strength obtained is $1.76 \mathrm{MPa}$ and $1.83 \mathrm{MPa}$ at 7 and 28 days respectively.

vi. Flexural strength obtained is $3.62 \mathrm{MPa}$ and 4.36MPaat 7 and 28 days respectively.

vii. At 5\% replacement $\mathrm{SBE}$ has maximum compressive strength at 7 days $34.44 \mathrm{MPa}$ and 28 days $42.88 \mathrm{MPa}$ when compared with remaining percentages.

viii. Split tensile strength obtained is $1.27 \mathrm{MPa}$ and $1.55 \mathrm{MPa}$ at 7 and 28 days respectively.

ix. Flexural strength obtained is $3.73 \mathrm{MPa}$ and $5.08 \mathrm{MPa}$ at 7 and 28 days respectively.

x. With combined optimum\% replacement of RHA and SBE in cement with $w / c=0.38$ workability decreased. The compressive strength of $27.77 \mathrm{MPa}$ and $40.11 \mathrm{MPa}$ were observed at 7 and 28 days respectively.

xi. Split tensile strength obtained is $1.41 \mathrm{MPa}$ and $2.47 \mathrm{MPa}$ at 7 and 28 days respectively.

xii. Flexural strength obtained is $3.22 \mathrm{MPa}$ and $4.90 \mathrm{MPa}$ at 7 and 28days respectively. 


\section{Strength and Durability Research on Concrete with Partial Replacement of Cement by Rice Husk Ash and Spent Bleaching Earth}

xiii. Compressive strength gaining of SBE was slow at early ages, as the days progressed rate of gaining increased when compared with control mix.

xiv. The effect of using optimum contents of RHA, SBE as partial replacement of concrete has better resistance to acid than control concrete.

$\mathrm{xv}$. The weight loss is reduced for the specimen immersed in Hydrochloric acid after 28 days than control specimen due to simultaneous replacement of RHA and SBE.

xvi. Likewise compressive strength of concrete with SBE after 28 days immersion in Hydrochloric acid is $1.734 \%$ lesser than the concrete with 28 days water immersion.

$\mathrm{xvii}$. It was found that there is a beneficial effect of incorporating combination of RHA and SBE on concrete Hydrochloric acid resistance.

\section{REFERENCES}

1. E. Arunakanthi and H. Sudarsana Rao, "Effects of Sulphuric Acid in Mixing and Curing Water on Strength of High Performance Phosphogypsum Concrete", IJSTE International Journal of Science Technology \& Engineering, Volume 2,Issue 08, February 2016.

2. V. Ramasamy, "Compressive Strength and Durability properties of Rice Husk Ash Concrete KSCE Journal of Civil Engineering, Volume 16,Issue 01, pp 93-102, January 2012.

3. Chia khai tee, A project submitted to civil engineering and earth resources university Malaysia Pahang under title "performance of spent bleaching earth as cement replacement in concrete", Nov 2010

4. Lina yl chong ann, A project submitted to civil Engineering and Earth Resources University Malaysia Pahang and under title "strength of concrete with spent bleaching earth as cement replacement", Nov 2010

5. Wachira J, Muthengiawa-Thiong'o J.Karanja, Gerald K.Muthakia,"Spent Bleaching Earth as a Pozzolanic Material" African Journals(AJOL), Vol.2,Issue 01,2005.

6. R.Ilangovana, N.Mahendrana and K. Nagamanib, "Stength and durability properties of concrete containing quarry rock dust as fine aggregate", ARPN Journal of Engineering and Applied Sciences, Volume 3, Issue 05, October 2008, ISSN 1819-6608, ISSN (online): 2349-784X.

7. Ogork, E.N; Aboshio, A. and Balami, D.A, "Durability Assessment of Concrete Made with Rice Husk Ash as Admixture", Journal of Engineering and Technology (JET), Volume 05,Issue 01, February 2010.

8. Arvind Kumar, Amit Kumar Tomar , Shravan Kishor Gupta, Ankit Kumar, "Replacement of Cement in Concrete with Rice Husk Ash", SSRG International Journal of Civil Engineering (SSRG-IJCE), Volume 3,Issue 07, July 2016.

9. Soh KheangLoh, StephenJames, MuzzamilNgatiman, Kah YeinCheong, Yuen MayChoo, Weng SoonLim, "Enhancement of palm oil refinery waste - Spent bleaching earth (SBE) into bio organic fertilizer and their effects on crop biomass growth", ELSEVIER, Volume 49,PP 775-781, August 2013. 